\title{
Pulmonary Single Circulation Dilution Curves of T-1824, Sodium, and Tritiated Water in Intact Piglets
}

\author{
O. ROBERT LEVINE( ${ }^{(2 \pi)}$ AND ERLINDA BANSIL \\ Department of Pediatrics, New Jersey Medical School, College of Medicine and Dentistry of New Jersey, Newark. \\ New Jersey, USA
}

\begin{abstract}
Summary
In order to assess pulmonary endothelial permeability to sodium in the immature lung, 15 multiple indicator dilution curves were done in eight intact piglets. An indicator bolus consisting of T-1824, ${ }^{2}-\mathrm{Na}$, and tritiated water (THO) was delivered into the right atrium and blood was sampled from the aorta. The concentration of sodium, expressed as a fraction of the quantity injected and of the corresponding fractional concentration of $T-1824$, was averaged for the samples prior to recirculation. The permeability-surface area product calculated from these data is $2.0 \times$ $10^{-5} \mathrm{~cm} \mathrm{sec}$, and is virtually identical with the value reported elsewhere for adult dogs. Extravascular lung water obtained from the tritiated water and $\mathrm{T}-1824$ curves averaged $64 \%$, whereas that obtained from the ${ }^{2: 2} \mathrm{Na}$ and $\mathrm{T}-1824$ curves averaged $23 \%$ of blood-free lung water.
\end{abstract}

\section{Speculation}

Several lines of evidence indicate that the endothelium of the immature lung may permit edema formation more readily than that of the adult lung. However, no differences have been found with regard to transendothelial passage of protein molecules or of the sodium ion. We still have no satisfactory explanation for hyaline membrane formation in the respiratory distress syndrome of prematurity. Such information may be provided by the application in prematurely delivered fetuses of techniques available for the assessment of pulmonary capillary permeability.

Studies of pulmonary transcapillary exchange in immature animals are of interest in relation to clinical problems such as pulmonary edema, hyaline membrane discase, and resorption of lung fluid at birth (14). Passive transport across a blood-tissue barrier is characterized according to nonequilibrium thermodynamics (11) by three independent parameters: filtration coefficient, permeability-surface area product, and reflection coefficient. In regard to the filtration coefficient, a previous study (17) demonstrated that the rate of fluid accumulation during hemodynamic pulmonary edema was greater in the lungs of puppies than aduli dogs, yiclding estimates of the filtration coefficient which differed by 1-2 orders of magnitude. In a companion to the present study (unpublished observations) the filtration coefficient was measured in isolated, perfused piglet lungs and found to be more than twice that previously obtained in adult dog lungs by similar techniques (19).

Pulmonary capillary permeability has been assessed in the lungs of adult dogs by the multiple indicator dilution technique, using a variety of hydrophilic and lipophilic indicators $(2,4,5$, $20)$. The theory and application of this method to the derivation of the permeability-surface area products (PS) have been presented $(6,20)$. The present study reports the PS of the piglet lung endothelial barrier to sodium ion.

\section{METHODS}

Piglets were obtained through a commercial supplier from working farms and had been born spontaneously, presumably at term. Eight piglets, 2-8 weeks of age. weighing $2.6-5.8 \mathrm{~kg}$, were anesthetized with pentobarbital, $20 \mathrm{mg} / \mathrm{kg}$, administered intraperitoneally. Catheters were inserted into an external jugular vein and a carotid artery, and were passed into the right atrium and aortic arch, respectively. An endotracheal tube was inserted through a tracheostomy. The animals were maintained in the supine position, breathing room air spontaneously, and the lungs were hyperinflated at intervals to prevent atelectasis. Heparin was administered, and a blood sample was withdrawn for the preparation of indicator standards. An indicator bolus was injected into the right atrium. The bolus consisted of 'T-1824 $10 \mathrm{mg},{ }^{2 \cdot} \mathrm{NaCl} 10 \mu \mathrm{Ci}$, and $\mathrm{THO} 20 \mu \mathrm{Ci}$. Blood was collected from the arterial catheter by opening a stopeock and allowing free flow into test tubes mounted on a turntable rotating at a rate which provided samples of $0.5-1 \mathrm{ml}$ each $0.5 \mathrm{sec}$. The study was done twice in each piglet, with an interval of $10-15$ min between runs.

The blood samples were analyzed for T-1824 concentration by spectrophotometry, for THO by liquid scintillation, and for ${ }^{2:} \mathrm{Na}$ by $y$ counting. Utilizing all the samples on the ascending limb of the time-concentration curves, and the first sample on the descending limb, the indicator concentrations, in milligrams or counts per ml of blood, were expressed as a fraction of the injected quantity of indicator. The fractional concentration of "2Na in each sample was then expressed as a proportion of the corresponding fractional concentration of $T-1824$, and these were averaged to yield $T_{a v}=1-E_{a v}$ where $E_{a v}$ is denoted the average extraction (6).

Blood flow $(F)$ was obtained from the $T-1824$ time-concentration curve after semilogarithmic plotting of the downslope to correct for recirculation, in the usual fashion. Extravascular lung water was obtained as the product of blood flow and the difference between THO and T-1824 mean transit times, using the formula $\Delta \mathrm{V}_{\mathrm{THO}}=\mathrm{F}_{\mathrm{b}} \mathrm{f}_{\mathrm{b}}\left(\overline{\mathrm{t}}_{\mathrm{TH3})}-\overline{\mathrm{t}}_{\mathrm{T}-1 \mathrm{k24}}\right)(3,8)$. In this expression, $f_{b}$, the water fraction of whole blood, was determined experimentally by weighing an aliquot of blood and drying to constant weight. $\bar{t}_{\mathrm{T}-182.4}$, the mean transit time of the plasma label, was corrected for the more rapid transit of red blood cells through the pulmonary microcirculation by dividing by 1.06 , as described by Goresky et al. $(7,8)$ The extravascular dilution volume of the sodium tracer, $\Delta \mathrm{V}_{\mathrm{Na}}$, was obtained in a similar fashion.

In order to assess the recovery pattern of sodium in relation to that of T-1824 and tritiated water, the concentration of each indicator was expressed as a fraction of the injected quantity during the entire duration of the T-1824 curve, after the usual semilogarithmic correction for recirculation. Complete recovery of the plasma indicator was assumed. For each sample, the fractional concentration of the $\mathrm{Na}$ and of $\mathrm{THO}$ was expressed as 
a fraction of the corresponding fractional concentration of $T$ 1824, to yield the fractional recoveries of $\mathrm{Na}$ and THO in relation to the intravascular indicator. These data were averaged for the duplicate experiments in each animal, at 1-sec intervals (sec Table 2).

The volume of blood-free lung water was determined in the above animals, and in seven additional piglets similarly prepared but in which indicator dilution studies were not done. After exsanguination of the animal, the lungs were removed and urained passively of blood. Two $0.2-(0.3-\mathrm{g}$ sections were cut from each lung for determination of hemoglobin content. The lungs were weighed, dehydrated by successive 24 -hr immersion in absolute alcohol and acetone, and dried to constant weight in a drying oven to obtain total water content. Residual blood in the lung was measured spectrophotometrically after extracting the hemoglobin from the minced samples of lung in a cyanmethemoglobin solution (Drabkin's reagent). Blood water content was obtained by drying a weighed blood sample to constant weight in a drying oven. The amount of water contained in residual lung blood was subtracted from the total lung water content to obtain the volume of blood-free lung water. It was assumed that the water content of residual lung blood is the same as that of peripheral blood.

\section{RESULTS}

\section{SODIUM PERMEABILITY}

Each multiple-indicator dilution curve provided at least 4 points (range 4-8 points, average 5.5) for the calculation of $T_{a x}$, the transmission of sodium relative to $T-1824$ (Fig. 1). Fifteen technically satisfactory curves were obtained in eight piglets. For the calculation of $T_{a v}$ each curve was considered a separate experiment. $T_{a x}$ was $0.953 \pm 0.037$ (Table 1 ); this value is significantly different from unity $(P<0.01)$.

The recovery patterns of $\mathrm{Na}$ and THO relative to the intravascular indicator, T-1824, are shown in Table 2. The raw data

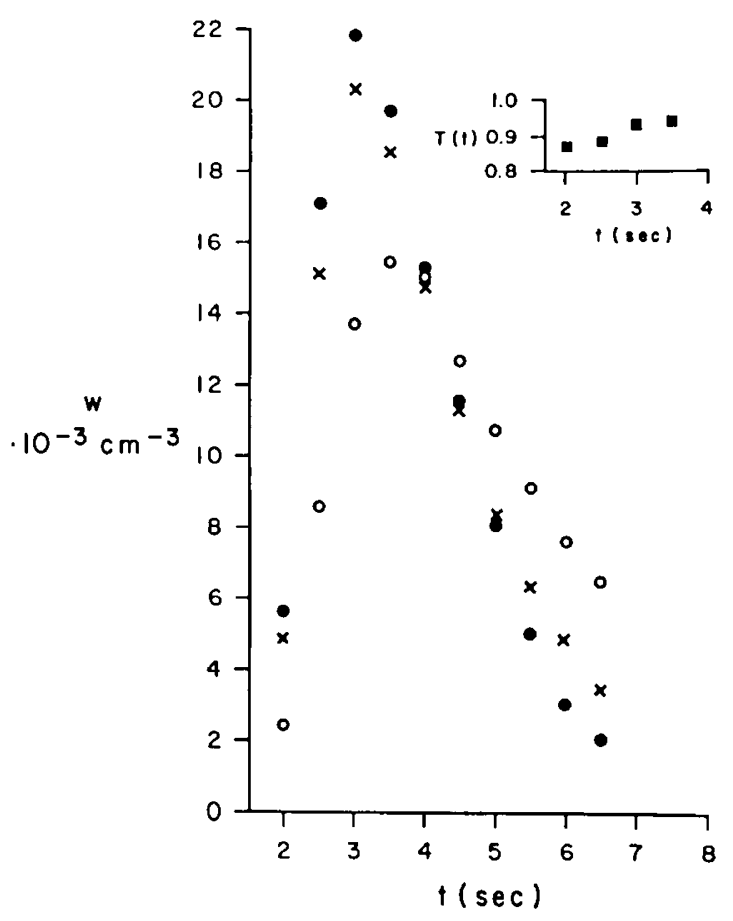

Fig. 1. Typical indicator dilution curves, Experiment 5-7A. w, the concentration of the indicator in each sample as a fraction of the amount injected, is plotted against t, the time interval after bolus injection. $\bullet: T$ 1824; $\times:{ }^{2 !} \mathrm{Na}$; O: tritiated water. Inset: $\mathrm{T}(\mathrm{t})$, the recovery ratios of ${ }^{2 \cdot 2} \mathrm{Na}$ in relation to $\mathrm{T} 1824$, are given for samples prior to recirculation (upstroke and first sample on downslope). have been summarized by averaging the values for the duplicate runs at $1-\mathrm{sec}$ intervals. Prior to the peak T-1824 concentration, occurring at $4-5 \mathrm{sec}$, fractional recovery of Na approaches but is slightly less than that of T-1824, whereas THO recovery is considerably smaller. On the downslope, after correction for recirculation, fractional Na recovery progressively exceeds that of T-1824, but lags behind that of THO. A representative set of curves is shown in Figure 1.

Pulmonary capillary permeability to sodium was calculated as a permeability-surface area product by the following formula (6)

$$
\mathrm{PS}=0.96(1-\mathrm{Hct}) \mathrm{F} \ln \mathrm{T}_{\mathrm{iv}}
$$

where $0.96=$ water content of plasma; $P=$ permeability coefficient in centimeters $\sec ^{-1}, \mathrm{~S}=$ endothelial surface area, assumed equal to $500 \mathrm{~cm}^{2} / \mathrm{g}$ wet lung (see "Discussion"); Het = flow hematocrit in pulmonary microvasculature, assumed equal to peripheral volume hematocrit (28\% in these animals); $\mathrm{F}=$ blood flow, in cubic centimeters $\sec ^{-1}$ per $100 \mathrm{~g}$ wet lung; and $\mathrm{T}_{\mathrm{av}}=$ average transmission of test indicator $\left({ }^{2-2} \mathrm{Na}\right)$ relative to $\mathrm{T}$ 1824. Thus, for $\mathrm{S}=500 \mathrm{~cm}^{2} \mathrm{~g}^{-1}, \mathrm{Hct}=0.28, \mathrm{~F}=29.9 \mathrm{~cm}^{3} \mathrm{sec}^{-1}$ $100 \mathrm{~g}$, and $\mathrm{T}_{\mathrm{av}}=0.953$, the permeability, $\mathrm{P}$, is: $\mathrm{P}=-1.92 \times$ $10^{-5} \times 0.72 \times 29.9 \times(-0.0481)=2.0 \times 10^{-5} \mathrm{~cm} \mathrm{sec}^{-1}$.

\section{PULMONARY FLUID VOLUMES}

The total lung water content obtained by drying whole lung tissue was $9.59 \pm 1.43 \mathrm{~cm}^{3} \mathrm{~kg}^{-1}$. Blood retained in lung tissue after exsanguination and draining the lungs from the hilar vessels contributed an average of $12.4 \%$ of the total lung water by drying. After correcting for retained blood, the water content of blood-free lung tissue was $8.40 \pm 1.47 \mathrm{~cm}^{3} \mathrm{~kg}$ '. The extravascular lung water, $\Delta \mathrm{V}_{\mathrm{TH}}$, determined by single circulation THO dilution, was $5.4 \pm 1.95 \mathrm{~cm}^{3} \mathrm{~kg}^{-1}$, averaging $64 \%$ of blood-frec lung water content (Table 1). The extravascular sodium dilution volume was $1.9 \pm 0.74 \mathrm{~cm}^{3} \mathrm{~kg}^{-1}$ (Table 1 ), averaging $23 \%$ of total lung water.

The water content of blood-free lung tissue correlated well with body weight $(r=0.68, P<0.01)$. There was no correlation of $\Delta \mathrm{V}_{\mathrm{THO}}$ with either body weight or total lung water content.

\section{DISCUSSION}

In the present study the relative impermeability of the pulmonary capillary membrane to sodium, well known in the adult lung $(2,4,5,19,20)$, was examined in the intact anesthetized piglet. The data obtained here indicate that with respect to sodium permeability, as determined by the single passage indicator dilution method, there is virtual identity between the piglet lung and the adult animal or human lung. This conclusion is based on the assumption that the exchanging endothelial surface area is the same in the piglet lung as in the adult $\mathrm{dog}, 500 \mathrm{~cm}^{2} / \mathrm{g}$ lung (22). Examination of this assumption in light of studies of lung development in young rats (1) and humans (10) reveals that the capillary surface area and the area of the alveolar air-tissue interface increase progressively with age. This increase is due both to an increasing number of alveoli and to change in their size and shape. Morphometric studies of alveolar and capillary surface area in young rats have demonstrated a proportionality between these parameters and overall lung size. However, the rate of increase in surface area is not constant, and direct extrapolation of these data to other species is not possible. Thus, although it seems reasonable to relate surface area to lung size, the lack of precise data for the piglet renders the permeability calculation an order-of-magnitude estimate. Also, since these animals were not delivered prematurely, the present study sheds no light on pulmonary capillary permeability in the fetal lung.

The recovery ratio of the sodium tracer, calculated from the carly portion of the dilution curves, increases progressively with time (Fig. 1, Table 2). Three factors may contribute to this phenomenon: back-diffusion, Taylor diffusion, and recirculation. Back-diffusion of a diffusion-limited tracer such as $\mathrm{Na}$ is 
Table 1. Experimental data; indicator dilution studies'

\begin{tabular}{|c|c|c|c|c|c|c|c|c|c|c|c|}
\hline \multicolumn{2}{|c|}{ Experiment no. } & \multirow{3}{*}{$\frac{\mathrm{BW}, \mathrm{kg}}{2.6}$} & \multirow{2}{*}{$\frac{M_{L}, g \text { wet }}{29.4}$} & \multirow{2}{*}{$\frac{\mathrm{M}_{\mathrm{L}}, \mathrm{g} \text { dry }}{4.6}$} & \multirow{2}{*}{$\begin{array}{c}\begin{array}{c}\mathrm{F}, \mathrm{cm}^{3} \\
\mathrm{sec}^{-1} / 100 \\
\mathrm{~g}\end{array} \\
35.3\end{array}$} & \multirow{2}{*}{$\frac{\mathrm{I}_{\mathrm{T}-1824}, \mathrm{sec}}{4.68}$} & \multirow{2}{*}{$\frac{\mathfrak{f}_{\mathrm{Na}}, \mathrm{sec}}{5.14}$} & \multirow{2}{*}{$\frac{\mathrm{t}_{\mathrm{rHo}}, \mathrm{sec}}{5.95}$} & \multirow{2}{*}{$\frac{T_{\mathrm{av}}}{0.97}$} & \multirow{2}{*}{$\frac{\begin{array}{c}\Delta \mathrm{V}_{\mathrm{THO}}, \\
\mathrm{cm}^{3} / \mathrm{kg}\end{array}}{4.5}$} & \multirow{2}{*}{$\frac{\begin{array}{c}\Delta \mathrm{V}_{\mathrm{Na}}, \\
\mathrm{cm}^{3} / \mathrm{kg}\end{array}}{1.6}$} \\
\hline $3-13$ & A & & & & & & & & & & \\
\hline & B & & & & 36.2 & 5.06 & 5.65 & 6.90 & 1.01 & 6.7 & 2.1 \\
\hline \multirow{2}{*}{$3-30$} & A & 4.3 & 52.1 & 9.0 & 34.6 & 3.98 & 4.31 & 5.97 & 1.02 & 7.2 & 1.2 \\
\hline & B & & & & 29.7 & 5.01 & 5.71 & 7.60 & 0.94 & 8.0 & 2.2 \\
\hline \multirow[t]{2}{*}{$4-24$} & A & 3.9 & 44.3 & 7.4 & 24.6 & 5.17 & 5.60 & 7.35 & 0.95 & 5.2 & 1.0 \\
\hline & B & & & & 22.0 & 6.24 & 6.81 & 8.41 & 0.93 & 4.5 & 1.2 \\
\hline \multirow{2}{*}{$4-30$} & A & 4.9 & 57.6 & 9.4 & 26.1 & 6.80 & 7.65 & 10.1 & 0.95 & 8.0 & 2.1 \\
\hline & B & & & & 15.3 & 9.90 & 11.7 & 13.9 & 0.98 & 6.5 & 2.7 \\
\hline \multirow[t]{2}{*}{$5-7$} & A & 3.6 & 49.4 & 7.1 & 35.0 & 3.54 & 4.25 & 5.56 & 0.91 & 8.3 & 2.9 \\
\hline & B & & & & 22.8 & 5.02 & 5.72 & 0.95 & 0.88 & 4.6 & 1.7 \\
\hline \multirow[t]{2}{*}{$4-13$} & A & 3.0 & 41.4 & 6.7 & 32.6 & 6.15 & 7.06 & 7.30 & 0.98 & 4.3 & 3.4 \\
\hline & $\mathrm{B}$ & & & & 19.6 & 6.90 & 7.96 & 8.48 & 0.93 & 3.6 & 2.4 \\
\hline $4-10$ & A & 3.9 & 42.3 & 6.9 & 18.4 & 9.40 & 10.6 & 11.7 & 0.92 & 3.9 & 2.0 \\
\hline \multirow[t]{3}{*}{$4-3$} & A & 5.8 & 53.7 & 8.8 & 55.0 & 2.71 & 2.94 & 3.28 & 0.97 & 2.5 & 1.0 \\
\hline & $\mathrm{B}$ & & & & 42.1 & 3.44 & 3.76 & 4.20 & 0.96 & 2.6 & 1.1 \\
\hline & $\mathbf{M}$ & 4.0 & 46.3 & 7.5 & 29.9 & 5.60 & 6.32 & 7.58 & 0.953 & 5.36 & 1.91 \\
\hline SD & & 1.02 & 8.91 & 1.56 & 10.4 & 2.05 & 2.42 & 2.74 & 0.037 & 1.95 & 0.74 \\
\hline $\mathrm{SE}$ & & 0.36 & 3.15 & 0.55 & 2.7 & 0.53 & 0.62 & 0.71 & 0.010 & 0.50 & 0.19 \\
\hline
\end{tabular}

' THO: tritiated water; BW: body weight; $\mathrm{M}_{\mathrm{L}}$ : lung weight; $\mathrm{F}$ : blood flow, from $\mathrm{T}-1824$ curve, per $100 \mathrm{~g}$ wet lung weight; $\mathrm{t}$ : mean transit time; $\mathrm{T}_{\mathrm{av}}$ : average fractional recovery of sodium on $\mathrm{T}-1824$ before recirculation; $\Delta \mathrm{V}_{\mathrm{TH}}$ : pulmonary extravascular THO dilution volume; $\Delta \mathrm{V}_{\mathrm{Na}}$ : pulmonary extravascular sodium dilution volume.

Table 2. Fractional recoveries $(R)$ of sodium and tritiated water (THO) in relation to T1824

\begin{tabular}{|c|c|c|c|c|c|c|c|c|c|c|c|c|c|c|}
\hline \multirow[b]{2}{*}{$t, \sec$} & \multicolumn{2}{|c|}{ Exp $3-13$} & \multicolumn{2}{|c|}{ Exp. 3-30 } & \multicolumn{2}{|c|}{ Exp. 4-24 } & \multicolumn{2}{|c|}{ Exp. 4-30 } & \multicolumn{2}{|c|}{ Exp. 5-7 } & \multicolumn{2}{|c|}{ Exp. 4-13 } & \multicolumn{2}{|c|}{ Exp. 4-3 } \\
\hline & $\begin{array}{c}\mathrm{R}_{\mathrm{Na}} \mathrm{a} \\
\mathrm{T} 1824 \\
\end{array}$ & $\begin{array}{c}\mathrm{R}_{\mathrm{THow}} / \\
\mathrm{T} 1824\end{array}$ & $\begin{array}{c}\mathbf{R}_{\mathrm{Na}} / \\
\mathrm{T} 1824 \\
\end{array}$ & $\begin{array}{l}\mathrm{R}_{\text {тио口 }} \\
\mathrm{T} 1824 \\
\end{array}$ & $\begin{array}{c}\mathrm{R}_{\mathrm{Na}} / \\
\mathrm{T} 1824 \\
\end{array}$ & $\begin{array}{l}\mathrm{R}_{\text {Tirol }} \\
\mathrm{T} 1824 \\
\end{array}$ & $\begin{array}{c}\mathrm{R}_{\mathrm{Na}} / \\
\mathrm{T} 1824 \\
\end{array}$ & $\begin{array}{c}R_{\text {THod }} \\
\text { T1824 }\end{array}$ & $\begin{array}{c}\mathrm{R}_{\mathrm{Na}} / \\
\mathrm{T} 1824 \\
\end{array}$ & $\begin{array}{c}\mathrm{R}_{\mathrm{THol}} \\
\mathrm{T} 1824 \\
\end{array}$ & $\begin{array}{c}\mathrm{R}_{\mathrm{va} /} \\
\mathrm{T} 1824 \\
\end{array}$ & $\begin{array}{l}\mathrm{R}_{\mathrm{THO}} \\
\mathrm{T} 1824\end{array}$ & $\begin{array}{c}\mathrm{R}_{\mathrm{Na} a} / \\
\mathrm{T} 1824\end{array}$ & $\begin{array}{c}R_{\text {THo/ }} \\
T 1824 \\
\end{array}$ \\
\hline 2 & & & & & & & & & & & 0.94 & 0.65 & 0.93 & 0.63 \\
\hline 3 & 1.0 & 0.58 & 0.85 & 0.50 & 0.87 & 0.45 & & & 0.89 & 0.59 & 0.90 & 0.79 & 0.97 & 0.83 \\
\hline 4 & 1.0 & 0.71 & 1.00 & 0.82 & 0.94 & 0.68 & 0.92 & 0.49 & 0.92 & 0.85 & 0.98 & 0.89 & 0.99 & 1.08 \\
\hline 5 & 1.02 & 0.88 & 1.26 & 1.23 & 0.97 & 0.79 & 0.97 & 0.62 & 0.95 & 1.00 & 0.99 & 0.93 & 1.02 & 1.35 \\
\hline 6 & 1.06 & 1.10 & 1.23 & 1.61 & 0.99 & 0.93 & 0.98 & 0.73 & 1.22 & 1.80 & 1.01 & 0.95 & 1.11 & 1.70 \\
\hline 7 & 1.14 & 1.30 & 1.19 & 2.05 & 0.97 & 1.04 & 1.00 & 0.89 & 1.57 & 2.91 & 1.04 & 0.95 & 1.18 & 2.08 \\
\hline 8 & 1.31 & 1.72 & 1.15 & 2.60 & 1.00 & 1.29 & 1.05 & 1.04 & 1.55 & 3.45 & 1.06 & 1.05 & 1.24 & 2.92 \\
\hline 9 & 1.35 & 2.15 & 1.09 & 3.54 & 1.00 & 1.51 & 1.09 & 1.14 & & & 1.08 & 1.08 & 1.50 & 3.30 \\
\hline 10 & 1.53 & 2.69 & 1.04 & 4.10 & 1.04 & 1.76 & 1.09 & 1.22 & & & 1.10 & 1.08 & & \\
\hline 11 & 1.63 & 3.49 & & & 0.98 & 1.99 & 1.08 & 1.35 & & & 1.08 & 1.11 & & \\
\hline 12 & 2.24 & 5.27 & & & 1.00 & 2.36 & 1.12 & 1.43 & & & 1.13 & 1.13 & & \\
\hline 13 & & & & & 0.99 & 2.76 & 1.10 & 1.59 & & & 1.22 & 1.14 & & \\
\hline 14 & & & & & 1.02 & & 1.12 & 1.72 & & & & & & \\
\hline
\end{tabular}

Table 3. Experimental data; lung fluid

\begin{tabular}{|c|c|c|c|c|}
\hline & $N$ & Mean & SD & $\mathrm{SE}$ \\
\hline Body weight (kg) & 16 & 4.76 & 2.26 & 0.56 \\
\hline Dry lung weight $(\mathrm{g})$ & 16 & 8.50 & 3.15 & 0.79 \\
\hline Total lung water (g/g dry) & 16 & 6.17 & 0.35 & 0.79 \\
\hline Total lung water $\left(\mathrm{cm}^{3} \mathrm{~kg}^{-1}\right)$ & 16 & 9.59 & 1.43 & 0.36 \\
\hline Lung water, bloodless $\left(\mathrm{cm}^{3} \mathrm{~kg}^{-1}\right)$ & 16 & 8.40 & 1.47 & 0.37 \\
\hline $\begin{array}{l}\text { Extravascular tritiated water }\left(\mathrm{cm}^{3} \mathrm{~kg}^{-1}\right) \\
\text { volume }\end{array}$ & 8 & 5.4 & 1.95 & 0.56 \\
\hline
\end{tabular}

unlikely to significantly distort the early portion of the curve (9), and it has been suggested that this effect is negligible as far on the downslope as $40 \%$ of the peak concentration (12). For this reason the calculation in the present study was restricted to the upstroke and the first point after the peak of the curve. Separation of the tracers within the vascular compartment may occur because of differences in diffusibility and hence in intravascular dispersion ('Taylor diffusion'), giving rise to changing concentration ratios with time (12). Early recirculation of indicators via small circulatory shunts cannot be excluded. However, this ef- fect is probably negligible in the present context because the poorly diffusible indicators would tend to recirculate together, retaining their relative concentration ratios on the early portion of the curves. It has been shown (21) that shunting through a patent ductus arteriosus is virtually absent in newborn swine by $48 \mathrm{hr}$ of age.

The present study demonstrates, in accord with others (15, 16), the inability of tritiated water to measure the total extravascular fluid space of the lung (Table 2). Thus, $\Delta \mathrm{V}_{\text {THo }}$ averaged $64 \%$ of total lung water (bloodless) in these piglets, which compares well with $76 \%$ obtained by similar techniques in adult dogs (13). Since the capillary endothelium is highly permeable to water this may be related to the inaccessibility of some portion of the extravascular fluid volume to the indicator during a single transit through the lung. The boundaries of the equilibration volume have not been defined, but it has been shown that the dilution volume is sensitive to alterations in lung perfusion (13, 16). The sodium tracer is diffusion limited and its dilution volume is consistently slightly greater than that of an intravascular indicator. Thus in the present study $\Delta \mathrm{V}_{\mathrm{Na}}$ measured $23 \%$ of total lung water (bloodless) in contrast to $64 \%$ measured by the water tracer. According to Perl et al. (20), the conventional 
method of correction for recirculation may mask a significant extravascular dilution volume for sodium by neglecting a prolonged, slow back-diffusion of the tracer from the extra- to the intravascular compartment. The data in Table 2 demonstrate that, in relation to the intravascular indicator, sodium diffuses back into the vascular compartment after the peak of the T-1824 curve. Its rate of back-diffusion is less than that of tritiated water, which is considered to be flow rather than diffusion limited. The true extravascular sodium dilution volume may therefore be underestimated by the usual treatment of the indicator dilution data. Although experimental verification of this notion is not available, it is compatible with the observation that expansion of the extravascular fluid volume is associated with a decrease in sodium recovery (18).

\section{CONCLUSION}

The multiple indicator dilution technique has been used to obtain an estimate of pulmonary endothelial permeability to sodium ion in intact piglets. Based on an assumed value for endothelial surface area, the permeability-surface area product was found to be virtually identical to that reported elsewhere for adult dogs. Although other studies have demonstrated a greater propensity of the immature lung for water filtration, the single circulation indicator dilution data demonstrate that immature and adult lungs are essentially equal calculated values for permeability to sodium.

Note Added in Proof. On the basis of these and related considerations (Chinard, F. P., Personal communication), it has been suggested that significant back-diffusion of the $22 \mathrm{Na}$ may be occurring during the up-slope portion of the indicator-ditution curves. Values for sodium permeability presented here and by Perl e't al. (20) may therefore be underestimates.

\section{REFERENCES AND NOTES}

1. Burri, P. H., Dbaly, J., and Weibel, E. R.: The postnatal grouth of the rat lung. I. Morphometry. Anat. Rec. 178: 711 (1974)

2. Chinard, F. P.: Permeability of the pulmonary blood-gas barrier. In: N. A. Lassen and C. Crone: A. Benzon Symposium II, Capillary Permeability, Pp. 605-613 (Academic Press, New York, 1970).

3. Chinard, F. P.: Estimation of extravascular lung water by indicator-dilution techniques. Circ. Res., 37: 137 (1975).

4. Chinard, F. P., and Enns, T.: Transcapillary pulmonary exchange of water in the dog. Amer. J. Physiol., 178: 197 (1954).

5. Chinard, F. P., Enns, T., and Nolan, M. F.: Pulmonary extravascular water volumes from transit time and slope data. J. Appl Physiol. 17: 179 (1962).

6. Crone, C.: The permeability of capillaries in various organs as determined by use of the "indicator diffusion" method. Acta Physiol. Scand., 58: 292 (1963).

7. Goresky, C. A., Chinard, F. P., Cronin, R. F. P., and Wangel, B. E.: Extravascular water space. In: C. Giuntini: Central Hemodynamics and Gas Exchange, pp.449-458 (Minerva Medica, Torino, 1971).

8. Goresky, C. A., Cronin, R. F. P., and Wangel, B. E.: Indicator dilution measurements of extravascular water in the lungs. J. Clin. Invest., 48: 487 (1969).

9. Guller, B., Yipintsoi, T., Orvis, A. L., and Bassingthwaite, J. B.: Myocardial sodium extraction at varied coronary flows in the dog. Circ. Res., 37: 359 (1975).

10. Hislop, A., and Reid, L.: Development of the acinus in the human lung. Thorax, 29: $90(1974)$.

11. Keclem, O., and Katchalsky, A.: Thermodynamic analysis of the permeability of biological membranes to non-electrolytes. Biochim. Biophys. Acta, 27: $229(1958)$.

12. Lassen, N. A. and Crone, C.: The extraction fraction of a capillary bed to hydrophilic molecules. In: N. A. Lassen and C. Crone: A. Benzon Symposium II, Capillary Permeability, pp.48-59 (Academic Press, New York. 1970).

13. Levine, $O$. R. and Mellins, R. B.: The assessment of lung perfusion by measurement of extravascular lung water. In: C. Giuntini: Central Hemodynamics and Gas Exchange (Minerva Medica, Torino, 1971).

14. Levine, O. R., and Mellins, R. B.: Liquid balance in the lung and pulmonary edema. In: E. M. Scarpelli: Pulmonary Physiology of the Fetus, Newborn and Child. (Lea and Febiger, Philadelphia, 1975).

15. Levine, O. R., Mellins, R. B., and Fishman A. P.: Quantitative assessment of pulmonary edema. Circ. Res., 17: $414(1965)$.

16. Levine, O. R., Metlins, R. B., and Senior, R. M.: Extravascular lung water and distribution of pulmonary blood flow in the dog. J. Appl. Physiol., 28: $166(1970)$.

17. Levine, O. R., Rodriguez-Martinez, F., and Mellins, R. B.: Fluid filtration in the lung of the intact puppy. J. Appl. Physiol., 34: 683 (1973).

18. Pcarce, M1. L. : Sodium recovery from normal and edematous lungs studies by indicator dilution curves. Circ. Res., 24: $815(1969)$.

19. Perl, W., Chowdhury, P., and Chinard, F. P.: Reflection coefficients of dog lung endothelium to small hydrophilic solutes. Amer. J. Physiol., 228: 797 (1975).

20. Perl, W., Silverman, F., Delea, A. C., and Chinard, F. P.: Permeability of dog lung endothelium to sodium, diols, amides, and water. Amer. J. Physiol., 230: 1708 (1976).

21. Rowe, R. D., Sinclair, J. D., Kerr, A. R., and Gage, P. W.: Duct flow and mitral regurgitation during changes of oxygenation in newborn swine. J. Appl. Physiol., 19: 1157 (1964).

22. Sicgwart, B., Gehr, P., Gil, J., and Weibel, E. R.: Morphometric estimation of pulmonary diffusion capacity. IV. The normal dog lung. Resp. Physiol., 13: 141 (1971).

23. The author is indebted to Dr. William Perl for encouragement and guidance.

24. This research was supported by National Heart and Lung Institute Grant HL $16409-(01$ and by General Research Support Grant 05393 from the National Institutes of Health to the New Jersey Medical School.

25. Requests for reprints should be addressed to: O. Robert Levine, M.D. Department of Pediatrics, New Jersey Medical School, 100 Bergen St., Newark, N. J. 07103 (USA).

26. Received for publication June $15,1976$.

27. Accepted for publication October 14, 1976. 